\title{
IAMJ
}

INTERNATIONAL

AYURVEDIC

MEDICAL JOURNAL

ISSN: 2320-5091

Impact Factor: 6.719

\section{CRITICAL REVIEW ON THE CONCEPT OF JATARAGNI}

\author{
Akshatha K ${ }^{1}$, Nagaraj $\mathrm{S}^{2}$, Ravi K.V. ${ }^{3}$, Arun Kumar $\mathrm{M}^{4}$ \\ ${ }^{1} \mathrm{PG}$ Scholar, Department of PG and PhD studies in Roganidana \\ ${ }^{2}$ Professor and HOD, Department of PG and PhD studies in Roganidana, \\ ${ }^{3}$ Assistant Professor, Department of Kriya Shareera, \\ ${ }^{4}$ Associate Professor, Department of PG and PhD studies in Roganidana, \\ Sri Dharmasthala Manjunatheshwara Ayurvedic College, Udupi, Karnataka, India
}

Corresponding Author: akshathak5757@gmail.com

https://doi.org/10.46607/iamj2909122021

(Published Online: December 2021)

Open Access

(C) International Ayurvedic Medical Journal, India

Article Received: 29/11//2021 - Peer Reviewed: 10/12/2021 - Accepted for Publication 11/12/2021

\section{Check for updates}

\begin{abstract}
Proper functions of Agni (fire) in the body signify good health of the individual while an abnormal state leads to manifestations of diseases. The word Jatara means Udara (abdomen) and the Agni located in Jatara is Jataragni (digestive fire) and its Pramana (quantity) differs in each organism. There are various anatomical structures related to Jataragni that contribute towards its normal functioning. The physiological process of digestion and metabolism including biophysical and biochemical changes in the ingested food is carried out by the influence of Jataragni. It also influences the status of Dosha, Dhatu and Mala in the body. The objective of this study is to know the anatomical and physiological aspects of Jataragni to understand the pathological states in the body.
\end{abstract}

Keywords: Agni; Jataragni; Koshtanga; Grahani.

\section{INTRODUCTION}

In Ayurveda, the term 'Agni' is concerned with the process involving heat. The ingested Ahara (food) gets transformed into Poshaka dhatu (nourishing tis- sue) by the influence of Agni and this includes chemical agencies responsible for Aharapachana (digestion of ingested food), separation of Sara bhaga (the 
nourishing part) and maintenance of proper metabolism in the body. Impairment in this can be a cause for the manifestation of diseases. Jataragni is the one which is located in Jatara pradesha (abdominal region) and does Aharapachana (digestion of ingested food).

\section{ANATOMICAL ASPECTS OF JATARAGNI}

The word Jatara means Udara and that which is related to Jatara is Jaatara ${ }^{1}$ and the Agni located in Jatara is Jataragni. Due to the Sukshma guna (subtle property) of Jataragni its presence cannot be perceived through Pratyaksha pramana (inspection) but is inferred through its Karya (effect) ${ }^{2}$.

The gastrointestinal tract can be compared to Koshta in Ayurveda, and it includes organs present in the thoracic and abdominal cavity ${ }^{3}$, organs which has embryological development from it and its functionally specialised part i.e., Amashaya(the stomach) Ashaya (site) containing Apakwa ama anna, Pakwashaya (the large intestine) - Ashaya containing Pakwa Anna after absorption of Sara amsha, Agnyashaya(the small intestine) - Ashaya located at Pakwamashaya madhya, Mutrashaya (the urinary apparatus), Rudhirashaya (the circulatory and haemopoietic system), Hrit (heart), Unduka (the caecum) and Phuphusa (lungs) ${ }^{6}$.

\section{Koshtanga}

Acharya Charaka and Vagbhata included visceral organs of the thoracic and abdominal cavity under the term Koshtanga. ${ }^{7,8,9}$.

Table 1: Number of Koshtanga according to different Samhita

\begin{tabular}{|l|l|l|}
\hline Samhita & Number & Koshtangas \\
\hline Charaka Samhita & 15 & $\begin{array}{l}\text { Nabhi, Hridaya, Kloma, Yakrit, Pleeha, Vrikka, Basti, Purishadhara, } \\
\text { Amashaya, Pakwashaya, Uttaraguda, Adharaguda, Kshudrantra, } \\
\text { Sthoolantra and Vapavahana. }\end{array}$ \\
\hline Ashtanga Hridaya & 12 & $\begin{array}{l}\text { Hridaya, Kloma, Phuphusa, Yakrit, Pleeha, Unduka, Vrikkau, Nabhi, } \\
\text { Dimba, Antra and Basti. }\end{array}$ \\
\hline Kashyapa Samhita & 13 & $\begin{array}{l}\text { Nabhi, Pleeha, Yakrit, Kloma, Hridaya, Vrikka, Guda, Basthi, Kshu- } \\
\text { dra antra, Shula antra, Amashaya, Pakvashaya and Vapa. } .\end{array}$ \\
\hline
\end{tabular}

\section{Grahani}

The term Grahani can be compared to the entire small intestine commencing from the Pylorus and ending with the ileocecal region. According to Vaidyaka Shabda Sindhu, the first part of Antra (intestine) is taken as Grahani, which is the seat of Agni as mentioned by Charaka and Sushruta. Acharya Charaka mentions Grahani which is located above Nabhi (umbelicus) as Agni Adhishtana as it holds the ingested Ahara $^{10}$ and Acharya Sushruta mentioned that the strength of Grahani depends on Agni and if Agni is impaired, Grahani gets affected ${ }^{11}$. In another context, Acharya Sushruta has mentioned Pittadhara kala as Adhishtana of Antaragni ${ }^{12}$.

Srotas related to gastrointestinal tract - Annavaha srotas

It has Amashaya and Vama parshwa as its Moola ${ }^{13}$, and it refers to the channel through which the process of transportation, digestion, absorption, nourishment and excretion takes place.

Dhamani related to gastrointestinal tract - Adhoga dhamani

Ingested Ahara which comes in contact with Pittashaya undergo Paka due to the presence of Ushmata (heat) and gets segregated, circulates from the Nabhi, madhya bhaga of Amapakwashaya and reaches the Hridaya which is Rasa sthana and does its Poorana (filling). Later it circulates through Urdhwaga and Tiryak Dhamani and nourishes the Sharira. Thus, does nourishment to the whole Sharira ${ }^{14}$.

\section{Jataragni Pramana}

In Bhela Samhita, Pramana of Jataragni has been mentioned according to the size of the Sharira as follows ${ }^{15}$ : 
Table 2: Pramana of Jataragni according to the size of the Sharira

\begin{tabular}{|l|l|}
\hline Size of the Sharira & Pramana \\
\hline Sthoola kaya individual & Yava pramana \\
\hline Hrswa kaya individual & Trutu pramana \\
\hline Krimi Keeta Patanga & Vayu pramana \\
\hline
\end{tabular}

\section{Physiological Aspects of Jataragni}

The food which is ingested must be transformed into the form which is utilised by the body for nourishment. Such transformation is carried out by the influence of Agni i.e., Jataragni, Bhootagni and Dhatwagni.

In Harita Samhita it is mentioned that initially, $\mathrm{Pa}$ chana (digestion) of ingested Ahara takes place by Jataragni ${ }^{16}$. The food taken through the mouth is carried by Prana vata and Kledana (moistening) of ingested Ahara by Kledaka kapha takes place. Then Samana vata, whose Sthana is mentioned as Agnisameepa holds Apakwa anna (undigested food) in Amashaya and does Agni Sandhukshana (ignition of digestive fire) which plays a role in digestive secretion resulting in Vibhajana (breaking down) of ingested food. Now the Pachaka pitta which is situated in Pakwamashaya madhya does Pachana (digestion) and sorts of Sara bhaga resulting in separation from Kitta bhaga (the excretory part). These Kitta bhaga moves downwards for excretion by the action of $\mathrm{Sa}$ mana vata and thereby gets expelled out of the body as Accha kitta - Mutra (urine) and Ghana kitta - Shakrit (faeces) by the influence of Apana vata.

The Sara bhaga of Ahara - Ahara rasa move from Pakwamashaya to Hridaya, the Sthana of Rasa dhatu through Dhamani. Then by the action of Rasa dhatwagni, Paka of Sthoola bhaga takes place nourishing Rasa dhatu and Sukshma bhaga reaches Yakrit and thereby digestion of the substance by the respective Bhootagni takes place i.e., Pritvyagni digests Prithvi mahabhuta pradhana substances ${ }^{17}$, Apyagni digests Ap mahabhuta pradhana substances and so on. Thus, causing an increase of Samana bhavas like Parthiva dravyas contributes to Parthiva constituents; Apya dravyas contributes to Ap constituents in the body. Then the end products of Jataragni are processed by Bhutagni which undergo Rasa shoshana and move towards Saptadhatus through respective Srotas by the action of Vyana vata. In brief, by the respective Dhatwagni paka, Poshaka dhatu is formed which nourishes Sapta dhatu and Upadhatu.

\section{Jataragni and Dosha}

- Jataragni and Vata Dosha: The karma of Jatarag$n i$ is influenced by Prana, Apana and Samana vata for the maintaining of Dhmapana, Palana and Swa karma just like wind acts on fire. ${ }^{18}$

- Jataragni and Pitta Dosha: Sthana of Pachaka pitta is Pakwamashaya madhya and its karma is Anna pachana, Vibhajana of Sara and Kitta bhaga. It has the predominance of Tejomahabhuta, and it enhances other types of Pitta. As it does Pakadi kriya it is also called as Anala. ${ }^{19}$

- Jataragni and Kapha Dosha: Sthana of Kledaka Kapha is Amashaya and its Karma is Anna sanghata. $^{20}$

\section{Jataragni and Dhatu}

Due to Abhojanadi ajeerna nidana (causes of indigestion), Dooshita (vitiated) Agni won't be able to digest even the ingested Laghu ahara (light food) resulting in the formation of Visharoopa anna (food with toxic properties). When this becomes severe it combines with each Dosha and Dhatu resulting in the respective structural and functional abnormalities. ${ }^{21}$ 


\section{Vata dosha $\Rightarrow$ Vataja rogas. \\ Visharoopa anna \\ Pitta dosha $\Rightarrow$ Daha, Trishna, Mukhamaya, Amlapitta and other Pittaja rogas. \\ Kapha dosha $\Rightarrow$ Yakshma, Peenasa, Meha and other Kaphaja rogas. \\ Dhatu $\Rightarrow$ Respective Dhatu pradoshaja vikaras.}

\section{Factors affecting Jataragni}

- Ahara matra: Matra of consumed Ahara affects Jataragni pravritti. So, Ahara should be consumed in a proper manner avoiding Asamyak yoga i.e., Sankeerna ashana (contaminated food), Viruddha ashana (incompatible food), Amatra ashana (food consumed not in accordance with prescribed quantity), Vishamashana (food consumed in inadequate quantity in improper time), etc.

- Ahara dravya: Properties of Ahara dravya affects the function of Agni. Example: Guru Dravya (heavy food substances) takes comparatively longer time to get digested.

- Ahara sevana Kaala: Food should be taken at a proper time i.e., after the digestion of a previous meal. If not, it may lead to the formation of Ama due to Jataragni mandya which later results in the manifestation of various diseases. It is also said that drinking water prior to meal lead to Krishata (emaciation) and after meal leads to Sthoulya (obesity).

- Manas: It plays an important role in maintaining the status of Jataragni i.e., the status of mind in an individual with Chinta, Shoka, Bhaya, Krodha, etc. results in Agnimandya.

- Vihara: Routine activities like Vyayama, Snana have an impact on Agni i.e., it increases the capacity of digestion.

- Rtu: In Hemanta and Shishira rtu, Agni will be Prabala and in Greeshma rtu, Alpa bala.

- Vikara: Mandagni is said to be the root cause for almost all diseases.

\section{Clinical Significance of Jataragni}

Ingested Ahara undergo Jataragni paka initially then Dhatwagni and Bhutagni paka take place at a later stage and these two are directly or indirectly dependent on Jataragni. Therefore, proper Jataragni is important for maintaining the Ayu and Bala of an individual. $^{22}$ The strength of Jataragni depends on the status of Grahani and impaired Jataragni affects Grahani leading to various diseases. Jataragni is responsible for Ayu, Varna, Bala, Swastha, Utsaha, Upachaya, Oja, Teja, Agni and Prana. ${ }^{23}$ Normal functions of Agni helps in proper physiological activities while abnormal state leads to disease manifestation and its absence causes death of the living beings.

Jataragni is classified into four types based on its digestive capacity. They are:

1. Samagni

2. Vishamagni

3. Teekshangni

4. Mandagni

1. Samagni - The Agni which digests the ingested Ahara taken in proper time without causing any discomfort is called Samagni. In this state of Agni, all Tridosha are in equilibrium and result in proper nourishment of the Dhatus and diseases caused in such individuals are considered to be Sukha sadya ${ }^{24}$ as the Agni does Dosha pachana, brings the vitiated Dosha to normalcy and thus help in gradual attainment of strength and maintain longevity.

2. Vishamagni - The Agni, which is irregular, which sometimes causes proper digestion and sometimes leads to symptoms like Adhmana (bloating), Shula (pain), Udavarta (a disease caused due to upward movement of Vata), Atisara (diarrhoea), Jatara gaurava (heaviness in the abdomen), Antra koojana (gurgling sound in the abdomen) and Pravahana 
(straining on defecation). This state of Agni results due to the influence of Vata dosha. ${ }^{24}$

3. Teekshnagni - The Agni digests the ingested food at a faster pace even if the food is taken in excess quantity i.e., it digests the heavy meal in a very short time. This can be seen in Pitta prakriti individual. Teekshnagni is of three types namely Ashupachana, Atyagni and Teekshnatamagni. It produces symptoms at the end of digestion like Gala shosha (dryness of throat), Talu shosha (dryness of palate) Oshta shosha (dryness of lips), Daha (burning sensation) and Santapa (raised temperature). It can be seen in diseases like Bhasmaka roga, Prameha, etc. ${ }^{24}$

4. Mandagni- The Agni which takes longer time for digestion of even a limited quantity of food is called Mandagni, and it produces Udara (abdominal distension), Shiro gaurava (heaviness in the head), Kasa (cough), Shwasa (dyspnoea) ${ }^{24}$. It is said that Mandagni is the cause for all diseases. When the ingested food is not digested properly or takes longer time, it leads to the formation of Ama in Koshta which later results in depletion of other types of Agni thereby affecting the nourishment of Saptadhatus and causing various diseases. It is observed in conditions like Jalodara (ascitis), Gulma, Grahani, Atisara (diarrhoea), Rasa pradoshaja vikara, etc. ${ }^{24}$

\section{DISCUSSION AND CONCLUSION}

Agni possessing Ashtamahaishwarya guna is Pittashrita i.e., it is located in the Sthana of Pachaka pitta-Pakwamashaya madhya and Dahana karma of Agni is a continuous process but being Sukshma, its functions can be perceived only through Anumana pramana. Agnidushti is caused due to the vitiation of Dosha Dushya by various factors like faulty food habits and activities followed by the individual. During Amla Avasthapaka taking place in Amashya which is predominant of Pitta dosha, if Guru ahara, which may be Matravat guru [light food substance taken in large quantity example: Mudga (green gram) in large quantity] or Gunavat guru [food substances which are heavy to digest example: Masha (black gram) ] are taken, process of digestion becomes slow and partially digested Ahara retains in the Amashaya for longer duration along with gastric juice which in turn causes Vidaha (burning sensation) in the chest and abdomen. Hence it is said that Mandagni is also the cause for Vidaha. So history of patient should be well understood before planning the treatment for the disease. In the context of Shodhana (purification therapy), it is necessary to bring the vitiated Dosha from all over the body to Koshta for expulsion. For this purpose, Snehana (oleation) and Swedana (sudation) is performed and prior to the internal Snehana therapy, Koshta and Jataragni of the individual should be assessed to fix the dosage of Sneha Aushadha suitable to that particular individual and even during the administration of Shamana Aushadha (palliative medicines), these are given prime consideration. Grahani is the Sthana of Agni and its impairment results in various diseases like Ajeerna, Alasaka, Visuchika, Grahani, Dhatu kshaya. Impairement of Grahani may present with the symptoms of malabsorption taking place in small intestine which in turn causes nutritional deficiency in the individual or excess production of digestive enzymes when there is insufficient food to be acted upon by Jataragni, it acts on the tissues of the gastrointestinal tract and later resulting in Dhatu paka. If there exists a defect in secreting cells of digestive enzymes, digestion process becomes slow due to insufficient enzymes leading to Mandagni. Jataragni converts the consumed Ahara into Ahararasa which after reaching the Hridaya gets transformed into Rasa dhatu. Duly formed Rasa dhatu nourishes all other Dhatus directly or indirectly resulting in the good health of the individual. Any impairment in the status of Jataragni leads to impairment in other Agni too, causing various diseases of respective Dhatus. So, status of Jataragni should be maintained by following proper dietary regimens.

\section{REFERENCES}

1. Acharya $Y T$, editor, Nibandhasangraha commentary of Sri Dalhana acharya on Sushrutha Samhita of Sushruta, Sutra Sthana; Athuropakramaneeya Adhyaya: Chapter 35, Verse 27. Varanasi: Choukambha Surabharati Prakashan,2019;154 
2. Acharya Y T, editor, Nibandhasangraha commentary of Sri Dalhana acharya on Sushrutha Samhita of Sushruta, Sutra Sthana; Athuropakramaneeya Adhyaya: Chapter 35, Verse 27. Varanasi: Choukambha Surabharati Prakashan,2019;154

3. Varier P S. Ashtanga shariram. $2^{\text {nded. }}$ Kottakal: The Arya Vaidya Sala: 1961:34

4. Varier P S. Ashtanga shariram. $2^{\text {nd }}$ ed. Kottakal: The Arya Vaidya Sala: 1961:33

5. Varier P S. Ashtanga shariram. $2^{\text {nd }}$ ed. Kottakal: The Arya Vaidya Sala: 1961:33

6. Acharya Y T, editor, Sushrutha Samhita of Sushruta, Chikitsa Sthana; Sadyovrana chikitsa: Chapter 2, Verse 12-3. Varanasi: Choukambha Surabharati Prakashan,2019;409.

7. Acharya Y T, editor, Charaka Samhita of Agnivesha, Sharira Sthana; Sharira sankya shariram: Chapter 7, Verse 10. Varanasi: Choukambha Surabharati Prakashan,2020;338.

8. Paradakara H S S, editor, Ashtangahrdaya of Vagbhata, Sharira Sthana; Angavibhagam Shariram: Chapter 3, Verse 12. Varanasi: Choukambha Sanskrit Sansthan,2016;387.

9. Bhisagacharya Satyapala, editor. Kashyapa Samhita\#ed. Varanasi: Choukambha Sanskrit Sansthan, 2015:112.

10. Acharya Y T, editor, Charaka Samhita of Agnivesha, Chikitsa Sthana; Grahani chikitsa: Chapter 15, Verse 56. Varanasi: Choukambha Surabharati Prakashan, 2020;517.

11. Acharya Y T, editor, Sushrutha Samhita of Sushruta, Uttara Sthana; Atisara Pratisheda chikitsa: Chapter 40, Verse 170.Varanasi: Choukambha Surabharati Prakashan,2019;709.

12. Acharya Y T, editor, Sushrutha Samhita of Sushruta, sharira Sthana; Adhyaya: Chapter 4, Verse 18. Varanasi: Choukambha Surabharati Prakashan,2019;356.

13. Acharya Y T, editor, Charaka Samhita of Agnivesha, Vimana Sthana; Sroto vimana: Chapter 5, Verse 8. Varanasi: Choukambha Surabharati Prakashan,2020;250.

14. Acharya Y T, editor, Nibandhasangraha commentary of Sri Dalhana acharya on Sushrutha Samhita of Sushruta, Sharira Sthana; Dhamani vyakaranam shariram: Chapter 9, Verse 7. Varanasi: Choukambha Surabharati Prakashan,2019;384-5.

15. Sri Abhay Katyayan, editors. Bhela Samhita. \#ed. Varanasi: Choukambha Publishing House;2009: 214.

16. Pandey Jaymini Vaidya, editors. Harita Samhita. \#ed. Delhi: Choukambha Bharati Academy; 2010:16.
17. Paradakara H S S, editor, Ashtangahrdaya of Vagbhata, Sharira Sthana; Angavibhagam Shariram: Chapter 3, Verse 60. Varanasi: Choukambha Sanskrit Sansthan, 2016;396.

18. Acharya Y T, editor, Sushrutha Samhita of Sushruta, Sutra Sthana; Athuropakramaneeya Adhyaya: Chapter 35, Verse 28. Varanasi: Choukambha Surabharati Prakashan,2019;824.

19. Paradakara H S S, editor, Ashtanga hridaya of Vagbhata, Sutra Sthana; Doshabediya adhyaya: Chapter 12, verse 10-2. Varanasi: Choukambha Sanskrit Sansthan,2016;193.

20. Paradakara H S S, editor, Ashtanga hridaya of Vagbhata, Sutra Sthana; Doshabediya adhyaya: Chapter 12, verse 16. Varanasi: Choukambha Sanskrit Sansthan,2016;194.

21. Acharya Y T, editor, Charaka Samhita of Agnivesha, Chikitsa Sthana; grahani chikitsa: Chapter 15, Verse 42-9. Varanasi: Choukambha Surabharati Prakashan,2020;517.

22. Acharya Y T, editor, Charaka Samhita of Agnivesha, Chikitsa Sthana; grahani chikitsa: Chapter 15, Verse 40. Varanasi: Choukambha Surabharati Prakashan,2020;516.

23. Acharya Y T, editor, Charaka Samhita of Agnivesha, Chikitsa Sthana; grahani chikitsa: Chapter 15, Verse 3. Varanasi: Choukambha Surabharati Prakashan,2020;512.

24. Acharya Y T, editor, Sushrutha Samhita of Sushruta, Sutra Sthana; Athuropakramaneeya Adhyaya: Chapter 35, Verse 24. Varanasi: Choukambha Surabharati Prakashan,2019;154.

\section{Source of Support: Nil Conflict of Interest: None Declared}

How to cite this URL: Akshatha K et al: Critical Review On The Concept Of Jataragni International Ayurvedic Medical Journal \{online\} 2021 \{cited December 2021\} Available from: http://www.iamj.in/posts/images/upload/3102_3107.pdf 